\title{
Morphometric Analysis of Dibru River Basin, Assam using Geo-Spatial Tools
}

\author{
Sonowal Gulap ${ }^{1}$, Thakuriah Gitika ${ }^{2}$ \\ ${ }^{1}$ Research Scholar, Geography Department, Cotton University, Guwahati, India \\ ${ }^{2}$ Assistant Professor, Geography Department, Cotton University, Guwahati, India
}

\begin{abstract}
Quantitative analysis of morphometric parameters helps in understanding the potential of the river basin as it helps in groundwater level management, soil properties and overall management system of the basin. It is necessary to study how fluvial landforms are formed, erosion and depositional works, and soil properties. Present paper deals with the aspects of morphometric parameters like stream order, stream number, basin area, drainage density, drainage frequency, slope with the contour interval of $10 \mathrm{~m}$, basin shape, basin length and long profile etc using Arc GIS 10.1 software. We try to evaluate all the three aspects of the morphometric analysis from the SOI toposheet. Based on all the morphometric analysis progress can make about the understanding of geohydrological nature of the natural system and influence on the significance of shaping the basin, their runoff characteristics, infiltration, permeability, erosional power of the river etc.
\end{abstract}

Keywords: morphometry, GIS

\section{Introduction}

Morphometry is define as the measurement and mathematical analysis of the configuration of the earth's surface, shape and dimension of its landforms [1]. Morphometric analysis is important in order to study the nature and behaviour of the drainage basin of the natural system. Hydrologic and geomorphic processes are responsible for the formation and development of morphometric parameters in a drainage basin. Basin is not only control by hydrologic but there is various aspects like climate, geologic, structural control of the lithological and vegetation etc. Various parameters of morphometric analysis are used in order to study the characteristics of the river by following the formula of some illustrious people [9]; [26]; [20]; [12]; [4]; [2]. The study of Quantitative parameters like Linear, Relief and Areal aspects are study with the used of software like Arc GIS 10.1 and try to find its relationship with one another in order to study the nature of drainage system. The relationship between the stream order and number of streams along with stream length just depend on the hydrologic, geologic, slope and vegetation cover. Nowadays GIS plays an important role in analysing the morphometric parameters and also helps in manipulation of spatial information. The techniques of GIS not only help in manipulation of spatial information but also help in identification of groundwater level potential, soil properties and overall management of the basin.

\section{Objectives}

The main objectives of this paper is-

1) To study the three aspects of morphometric parameters.

2) To analysis how these parameters helps in shaping a natural system.

\section{Geographical background of the study area}

The Dibru River is a left bank tributary of Brahmaputra River. The basin drain into the plain region of Assam experience the great sub Himalayan terrain and bounded by river Brahmaputra and Lohit in north, Noa Dihing River in the eastern and some tributaries of the Burhi Dihing River in the south and western borders of the basin. Geographically it latitude and longitudinal extension is $27^{\circ} 25^{\prime} 30^{\prime \prime} \mathrm{N}$ $27^{\circ} 46^{\prime} 30^{\prime \prime} \mathrm{N}$ and $95^{\circ} 6^{\prime} 0^{\prime \prime} \mathrm{E}-9^{\circ} 58^{\prime} 30^{\prime \prime} \mathrm{E}$ covering about 1779 sq km area of Tinsukia, Dibugarh, Dhemaji district of Assam and part of Arunachal Pradesh with ever-green and semi-deciduous forests and the climatic condition is high humidity and moderate temperature. The slope of the basin varies from gently slope to base level slope $\left(0^{\circ}-5^{\circ}\right)$. 


\section{International Journal of Science and Research (IJSR) \\ ISSN: 2319-7064}

ResearchGate Impact Factor (2018): 0.28 | SJIF (2018): 7.426

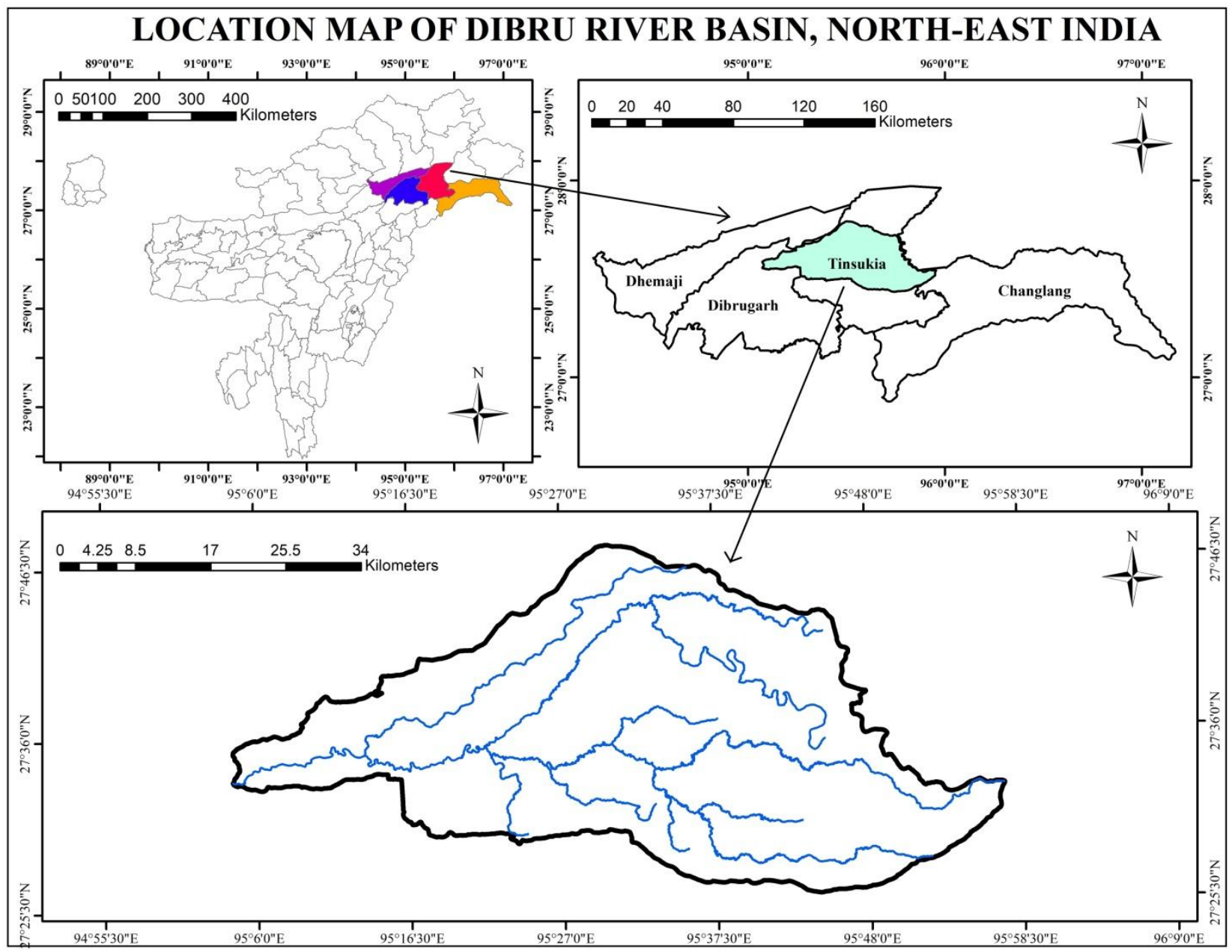

Figure 1: Location map of Dibru River Basin

1) Methodology and Data base:

The base map is prepared from the Survey of India (196366 ) bearing toposheet no $83 \mathrm{M} / 2,83 \mathrm{M} / 5,83 \mathrm{M} / 6,83 \mathrm{M} / 7$, $83 \mathrm{M} / 9,83 \mathrm{M} / 10,83 \mathrm{M} / 11,83 \mathrm{M} / 13,83 \mathrm{M} / 14$, and $83 \mathrm{M} / 15$ with scale 1:50,000 and contour interval $10 \mathrm{~m}$. Morphometric parameters of linear, relief and areal aspects of the Dibru basin are analysed using some mathematical and statistical formulas, graphs, cartograms and maps. The whole work is analysis in Arc GIS 10.1 software. Different formulas and their mathematical expression are shown in table 1.

Table 1: Morphometric parameters with formula and their mathematical expressions

\begin{tabular}{|c|c|c|c|}
\hline $\begin{array}{c}\text { S. } \\
\text { No: }\end{array}$ & Parameters & Formula & Indicate the values \\
\hline \multicolumn{4}{|c|}{ LINEAR ASPECTS: } \\
\hline 1. & Stream order A.N Strahler (1964) & $\overline{\mathrm{u}}$ & $\mathrm{U}$ is stream order \\
\hline 2. & Stream Numbers Horton (1945) & $\mathrm{N}$ & $\mathrm{N}$ is the stream segments of all the order \\
\hline 3. & Bifurcation ratio $(\mathrm{Rb})$ Horton (1945) & $\mathrm{Rb}=\mathrm{N}_{\mathrm{u}} / \mathrm{N}_{\mathrm{u}}+{ }_{1}$ & $\begin{array}{l}\text { Where } N_{u} \text { is the number of streams of any given order } \\
N_{u}+{ }_{1} \text { is the number of streams in the next higher order }\end{array}$ \\
\hline 4. & Stream length (Lu) (Horton,1945) & $\mathrm{Lu}$ & Lu is length of stream segment of all the stream order \\
\hline 5. & Stream Length ratio (RL) (Horton, 1945) & $\mathrm{RL}=\mathrm{L}_{\mathrm{u}} / \mathrm{L}_{\mathrm{u}-1}$ & $\begin{array}{l}\text { Where } L_{u} \text { is the mean streams of any given order } \\
L_{u^{-1}-1} \text { is the number of mean streams in the order }\end{array}$ \\
\hline 6. & Basin length (Lb) (Schumm ,1956) & $\mathrm{Lb}$ & $\begin{array}{c}\text { Lb is the longest dimension of the basin parallel to the } \\
\text { principal drainage line }\end{array}$ \\
\hline 7. & Length of Overland flow (Lg) (Chorley, 1977) & $\mathrm{Lg}=1 / 2 \mathrm{D}$ & D is Drainage density \\
\hline 8. & Lemniscate's (K) (Chorley, 1957) & $\mathrm{K}=\mathrm{Lb}^{2} / \mathrm{A}$ & $\mathrm{Lb}$ is basin length, $\mathrm{A}$ is basin area \\
\hline 9. & Sinousity Index (S.I) (J.C Brice,1964) & S.I=CL/MB & $\begin{array}{l}\text { CL is length of the channel and MB is length of meander } \\
\text { belt axis }\end{array}$ \\
\hline \multicolumn{4}{|c|}{ AREAL ASPECTS: } \\
\hline 10. & Form factor (Ff) (Horton's, 1932) & $\mathrm{Ff}=\mathrm{A} / \mathrm{Lb}^{2}$ & A is basin area, Lb is basin length \\
\hline 11. & Circularity Index (C) (V.C Miller's ,1953) & $\mathrm{C}=4 \Pi \mathrm{A} / \mathrm{p}^{2}$ & $\Pi$ is pi, $\mathrm{A}$ is basin area, $\mathrm{P}$ is basin perimeter \\
\hline 12. & Elongation ratio $(\mathrm{Re})($ Schumm's ,1956) & $\mathrm{Re}=2 / \mathrm{Lb}^{*}(\mathrm{~A} / \pi)^{0.5}$ & $\begin{array}{c}\mathrm{Lb} \text { is basin length, } \mathrm{A} \text { is basin area, } \Pi \text { is pi(value } 3.14) \\
0.5 \text { power value }\end{array}$ \\
\hline 13. & Area Ratio (A $\mu)($ Strahler, 1969) & $\mathrm{A} \mu=\mathrm{A}_{1} / \mathrm{A}_{1^{-}-1}$ & $\begin{array}{l}\text { Where } A_{1} \text { is the mean area of any given order } \\
A_{1^{-}} \text {is the number of mean area in the order }\end{array}$ \\
\hline
\end{tabular}

\section{Volume 8 Issue 8, August 2019} www.ijsr.net 
International Journal of Science and Research (IJSR)

ISSN: 2319-7064

ResearchGate Impact Factor (2018): 0.28 | SJIF (2018): 7.426

\begin{tabular}{|c|c|c|c|}
\hline 14. & Drainage density (Dd) (Horton, 1945) & $\mathrm{Dd}=\mathrm{L} / \mathrm{A}$ & $\begin{array}{l}\mathrm{L} \text { is total stream length } \\
\mathrm{A} \text { is basin area }\end{array}$ \\
\hline 15. & Drainage frequency (F) (Horton, 1945) & $\mathrm{F}=\mathrm{N} / \mathrm{A}$ & $\mathrm{N}$ is total stream number, $\mathrm{A}$ is basin area \\
\hline 16. & Drainage texture(Dt) (Horton, 1945) & $\mathrm{Dt}=\mathrm{Nu} / \mathrm{P}$ & $\begin{array}{l}\mathrm{Nu} \text { is the total number of stream segments of all order } \\
\mathrm{P} \text { is basin perimeter }\end{array}$ \\
\hline 17. & Infiltration Number (If) (Faniran,1968) & If $=F * \mathrm{Dd}$ & F is stream frequency and Dd is drainage density \\
\hline 18. & Texture ratio(Rt) (Schumm, 1965) & $\mathrm{Rt}=\mathrm{N}(1 / \mathrm{P})$ & $\begin{array}{l}\text { N1 is the stream segment of the first order, } \\
\text { P is the basin perimeter }\end{array}$ \\
\hline 19. & Constant of Channel Maintenance(C) (Schumm, 1956) & $\mathrm{C}=1 / \mathrm{Dd}$ & Dd is drainage density \\
\hline \multicolumn{4}{|c|}{ RELIEF ASPECTS: } \\
\hline 20. & Basin Relief(H) & $\mathrm{H}=\mathrm{Z} \sim \mathrm{Z}$ & $\begin{array}{l}\mathrm{Z} \text { is highest elevation of the basin } \\
\mathrm{z} \text { is the lowest elevation of the basin }\end{array}$ \\
\hline 21. & Relief Ratio (Rr) (Schumm, 1956) & $\mathrm{Rr}=\mathrm{H} / \mathrm{Lb}$ & $\mathrm{H}$ is Basin relief, $\mathrm{Lb}$ is the basin length \\
\hline 22. & Channel Slope (in degrees) & $\mathrm{S}=\tan ^{-1} \cdot \frac{V D}{H D}$ & $\begin{array}{l}\text { V.D is vertical distance of the slope } \\
\text { H.D is horizontal distance of the slope }\end{array}$ \\
\hline 23 & Slope ratio (Horton,1945) & $\mathrm{Rs}=\frac{S u}{S_{u+1}}$ & $\begin{array}{c}\text { Su is slope of a given order, } S_{u+1} \text { is slope of next higher } \\
\text { order }\end{array}$ \\
\hline 24. & Ruggedness Number (Rn) ( Patton \& Baker, 1976) & $\mathrm{Rn}=D d \cdot \frac{H}{1000}$ & $\begin{array}{l}\text { Dd is drainage density } \\
\mathrm{H} \text { is basin relief }\end{array}$ \\
\hline
\end{tabular}

\section{Result and Discussion}

\subsection{Linear Aspects}

\subsubsection{Stream order (u)}

The morphometric analysis of Dibru river basin is carried out by the hierarchical ranking method of A.N Strahler [26], any stream origin at the upper stage of the basin is identified as first order stream. According to Strahler method, two finger stream segment of first order meet it given birth to second order stream, two second order stream segment given birth third order stream and so on. If any lower order stream joins the higher order it doesn't change its order. It is observed that Dibru river basin is a sixth order river basin. The maximum stream frequency is observed at first order and second order stream. Hence it proved that stream frequency decrease with increasing order and vice versa and stream numbers also dependent on the type of lithology.

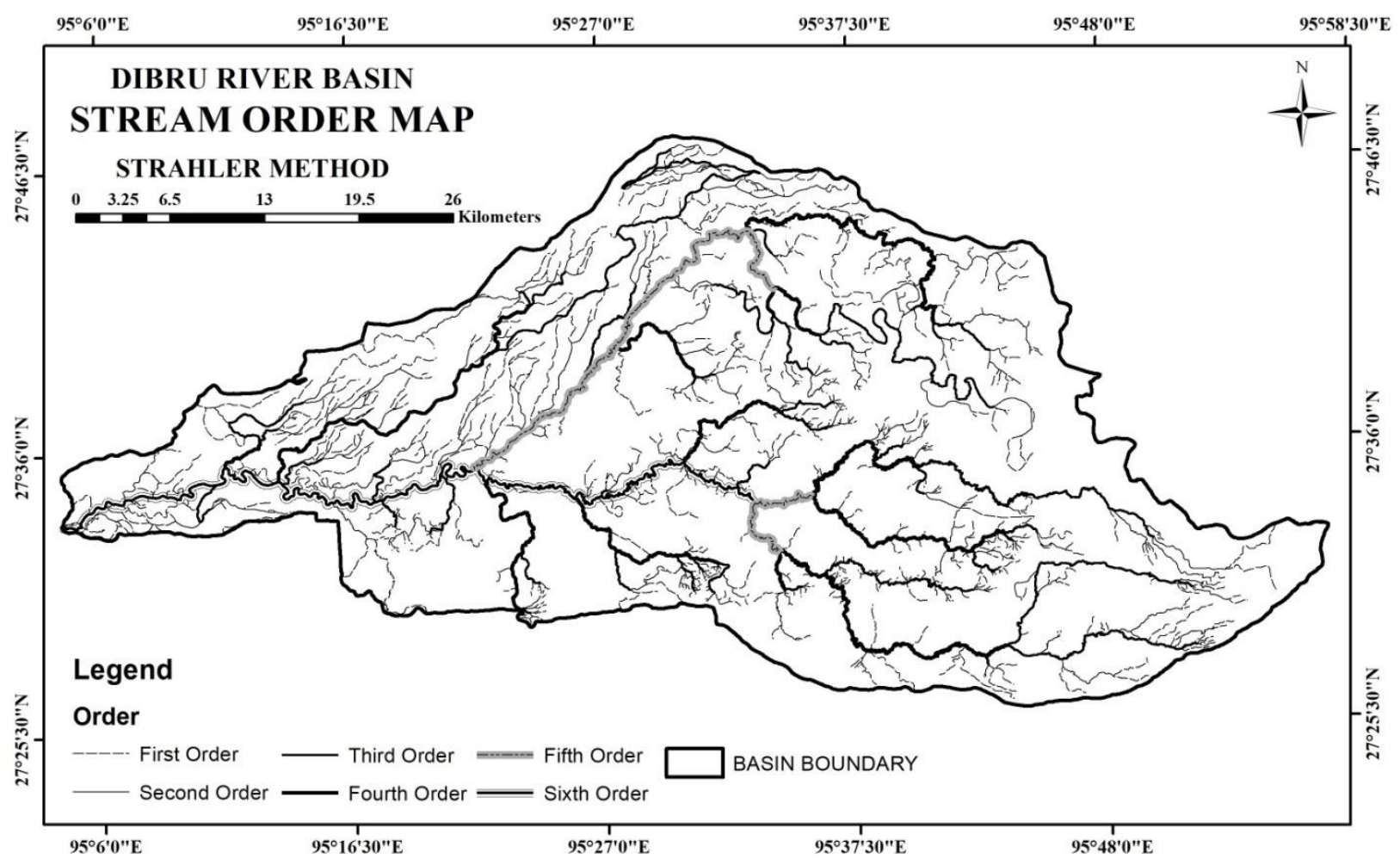

Figure 2: Stream order map

\subsubsection{Stream number $(\mathbf{N})$}

The drainage network map of the study area is carried out from SOI toposheet in Arc GIS platform. It is observed that there are 948 numbers of stream segments are found in Dibru river basin. The numbers of stream segment decreased with increasing order i.e. 693, 191, 47, 13, 3 and 1 numbers of stream segment in $1^{\text {st }}, 2^{\text {nd }}, 3^{\text {rd }}, 4^{\text {th }}, 5^{\text {th }}$ and $6^{\text {th }}$ order respectively. It may largely depend on physiographic, geomorphologic, and geological condition of landform.

\section{Volume 8 Issue 8, August 2019 www.ijsr.net}




\section{International Journal of Science and Research (IJSR) \\ ISSN: 2319-7064}

ResearchGate Impact Factor (2018): 0.28 | SJIF (2018): 7.426

\subsubsection{Bifurcation ratio $\left(R_{b}\right)$}

Bifurcation ratio is defined as the ratio of the number of stream segment in a given order $\left(\mathrm{N}_{\mathrm{u}}\right)$ to the number of stream of next higher order $\left(\mathrm{N}_{\mathrm{u}+1}\right)$. It is a dimensionless property of drainage basin which is controlled by drainage density, structural characteristics, basin shapes, basin area etc. According to R.E Horton, bifurcation ratio from about 2.00 represent flat or rolling basin, 3.0-4.0 represents mountainous or hilly dissected basin. The bifurcation ratio of Dibru river basin varies from 3.00-4.33 and the mean bifurcation ratio is 3.72 . The Dibru river basin is developed in flat landform and largely controlled with geology. There is variation in bifurcation ratio from lower order to higher order due to possibility in physiographic and lithological structure. It is observed from the table 2 that the bifurcation ratio of first order is 3.63 , second order is 4.06 , third order is 3.62 , fourth order is 4.33 and fifth order is 3 . The highest Bifurcation ratio is observed in higher order $\left(4^{\text {th }}\right.$ order $)$ and it means high structural controlled and low permeability over the area. Hence it proved that the hypothesis does not hold a strong based regarding the branching of network developed in the mountainous or hilly dissected region according to Horton.
Table 2: order wise stream number

\begin{tabular}{|c|c|c|}
\hline Order & No. of Stream & Bifurcation Ratio \\
\hline 1 & 693 & 3.63 \\
\hline 2 & 191 & 4.06 \\
\hline 3 & 47 & 3.62 \\
\hline 4 & 13 & 4.33 \\
\hline 5 & 3 & 3 \\
\hline 6 & 1 & - \\
\hline Total & 948 & \\
\hline
\end{tabular}

\subsubsection{Law of stream number}

Horton [9] states that the numbers of stream of different orders in a given drainage basin tend closely to approximate an inverse geometric series in which the first term is unity and the ratio is the bifurcation ratio. According to this law the stream number of Dibru basin is plotted against logarithmic scale on the $y$ axis and stream order on arithmetic scale on the $x$ axis. The number of stream from lower order to higher order gradually decreases with increasing order and there's relationship is negative correlation between them. The correlation coefficient is 1.31 .



Figure 3: Relationship between stream order and stream number

\subsubsection{Stream length (Lu)}

Length of streams in relation to order number is an important morphometric parameter in the study of the drainage characteristic of a basin. It is observed from the table that there is a positive correlated between stream order and mean stream length i.e. 1.31, 1.81, 5.90, 15.17, 17.76, and 75.18 from lower order to higher order 1,2,3,4, 5 and 6 respectively. The Higher number of stream with shorter length are observed where the lithological and bedrock are less permeable and lesser number of stream with longer stream length are observed where the landscape characteristics is permeable and well drained watershed. Total length of the stream in Dibru basin is $1863 \mathrm{~km}$. It is a well drained basin form over a plain topography.

Table 3: Order wise stream length characteristics

\begin{tabular}{|c|c|c|c|c|}
\hline Order & $\begin{array}{c}\text { No. of } \\
\text { Stream }\end{array}$ & $\begin{array}{c}\text { Stream } \\
\text { Length }(\mathrm{Km})\end{array}$ & $\begin{array}{c}\text { Mean Stream } \\
\text { Length }(\mathrm{Km})\end{array}$ & $\begin{array}{c}\text { Length } \\
\text { Ratio }\end{array}$ \\
\hline 1 & 693 & 913.28 & 1.31 & - \\
\hline 2 & 191 & 346.10 & 1.81 & 1.38 \\
\hline 3 & 47 & 277.69 & 5.90 & 3.25 \\
\hline 4 & 13 & 197.22 & 15.17 & 2.57 \\
\hline 5 & 3 & 53.30 & 17.76 & 1.17 \\
\hline 6 & 1 & 75.18 & 75.18 & 4.23 \\
\hline Total & 948 & 1863 & & \\
\hline
\end{tabular}

\subsubsection{Stream length ratio $\left(R_{L}\right)$}

Stream length ratio is defined as the ratio of the average stream length of a given order $\left(\mathrm{L}_{\mathrm{u}}\right)$ to the average stream length of preceding or lower order $\left(L_{u-1}\right)$. It can be expressed mathematically as-

$$
L u=\frac{L u}{L_{u-1}}
$$

Where, $\mathrm{L}_{\mathrm{U}}$ is the mean stream length of a given order and $\mathrm{L}_{\mathrm{U}-1}$ is the mean stream length of preceding order

From the table 3, it is observed that the stream length ration of Dibru basin is varies from 1.17 in $5^{\text {th }}$ order to 4.23 in $6^{\text {th }}$ order. This variation of the stream length ratio is depends on slope and topography and it also indicate the stage of the development of the river.

\subsubsection{Law of stream length}

According to Horton [9], the cumulative mean stream length of successive higher order increase in geometrical progression starting with the mean length of the first order segments with constant length ratio. According to this law the cumulative mean stream length of Dibru basin is plotted against logarithmic scale on the $y$ axis and stream order on arithmetic scale on the $x$ axis. The cumulative mean stream length gradually increase i.e. 1.31, 1.81, 5.90, 15.17, 17.76 and 75.18 with increasing order $1,2,3,4,5$ and 6 respectively 


\section{International Journal of Science and Research (IJSR) \\ ISSN: 2319-7064}

ResearchGate Impact Factor (2018): 0.28 | SJIF (2018): 7.426

and there's relationship is positively correlation between them. The correlation coefficient is 1.00.



Figure 4: Relationship between stream order and Cumulative mean stream length

\subsubsection{Basin perimeter $(P)$}

Basin perimeter is the outer edge of the watershed that enclosed its area. It is measured along the divides between watershed and may used as an indicator of watershed size and shape. The basin perimeter of Dibru basin is $233.54 \mathrm{~km}$.

\subsubsection{Basin length $(L b)$}

Schumm [20] defined basin length as the longest dimension of the basin parallel to the principal drainage line. The basin length of Dibru river basin is $87.13 \mathrm{~km}$.

\subsubsection{Length of Overland flow $(\mathrm{Lg})$}

The length of the overland flow is the mean horizontal length of the flow from the divide to the stream in a first order basin. It is a measure of stream spacing or degree of dissection, and is approximately one half the reciprocal of the drainage density [4]. The length of overland flow of Dibru main basin (0.48)

$$
\operatorname{Lg}=\frac{1}{2 D}
$$

Where, $\boldsymbol{D}$ is drainage density

\subsubsection{Lemniscate's $(K)$}

Chorley (1957) expressed the lemniscate's value to determine the slope of the basin. It is the ratio of square of the basin length to the basin area.

$$
K=\frac{L b^{2}}{A}
$$

Where, $\boldsymbol{L} \boldsymbol{b}$ is basin length and $\boldsymbol{A}$ is basin area

The Lemniscate's value of Dibru Basin is 4.26 which shows that maximum area in the region inceptions with large number of streams of higher order.

\subsubsection{Sinuosity Index (S.I)}

Channel Patterns of a drainage basin is identified with the help of Sinuosity Index. According to J.C Brice [2] Sinousity Index is the ratio of length of the channel to length of meander belt axis. It is a significant morphometric parameter which affects the terrain characteristics on the river course. Rivers having a sinuosity of 1.5 are called sinuous. The sinuosity index of Dibru River is found as 1.36 which shows that the head streams Dibru is sinuous in nature. It is a significant in the evolution of landscapes and beneficial for Geomorpologists, Hydrologists and Geologists.

\subsection{Areal Aspects}

\subsubsection{Basin shape}

Basin shape is an important areal aspect of the morphometric analysis. Basin shape can determine about the prediction of the runoff, overland flow and infiltration level in the basin. The ideal shape of the basin is usually of pear shape but since it is dependent on the size (of the basin) and the length of the antecedent stream of the basin and basin perimeter, which geological structure and lithological characteristics etc and hence a wide range of variation in basin shape is bound to happen. There are various methods to calculate basin shape and they are:

1) Form factor

2) Circularity ratio

3) Elongation ratio

\subsubsection{Form factor $(\mathrm{Ff})$}

Horton [8] define form factor as ratio of the area of the basin and square of the basin length. It is illustrated mathematically as-

$$
F f=\frac{A}{L B^{2}}
$$

Where $\mathrm{A}$ is the area of the basin and Lb is the basin length

The value of ' $F$ ' varies from 0 (highly elongated shape) to the unity i.e. 1 (perfectly circular shape). The Form factor of Dibru river basin is 0.23 and hence it proves that the basin is elongated in shape. The characteristic of elongated basin is that the outflow is longer in duration as compare to circular shape.

\subsubsection{Circularity ratio $(C)$}

V.C Miller's [12] stated that Circularity Index (C) is the ratio of the area of the basin to the area of circle having the same circumference as the perimeter of the basin.

The value of ' $\mathrm{C}$ ' varies from 0 (a line) to 1 (circle)

$$
C=4 \pi \frac{A}{p^{2}}
$$

Where, $\mathrm{A}$ is basin area and $\mathrm{P}$ is basin perimeter

Circularity ratio is mainly concerned with the length and frequency of streams, geological structures, land use / land cover, climate, relief and slope of the basin. Low, medium and high value of $\mathrm{c}$ indicates the young, mature and old stage of the life cycle of the tributary respectively. $\mathrm{C}$ value

\section{Volume 8 Issue 8, August 2019}




\section{International Journal of Science and Research (IJSR) \\ ISSN: 2319-7064}

ResearchGate Impact Factor (2018): 0.28 | SJIF (2018): 7.426

of Dibru river basin is 0.40 . According to Miller range, 0.40 indicates the elongated watershed in shape with low discharge of runoff and highly permeability of the subsoil condition.

\subsubsection{Elongation ratio $(R e)$}

According to Schumm's [20], Elongation ratio $(\mathrm{Re})$ is state as ratio of diameter of a circle of the same area as the basin to the maximum basin length

$$
R e=\frac{2}{L b} \times\left(\frac{A}{\pi}\right)^{0.5}
$$

Where $\mathrm{Lb}$ is basin length and $\mathrm{A}$ is basin area

The value of ' $R e$ ' varies from 0 (highly elongated shape) to 1 (circular shape). The value 0.52 indicates to be elongated in shape and flow for longer duration.

\subsubsection{Basin area $(\mathrm{A})$}

Basin area is another important parameter of morphometric analysis as like the relationship between stream length and stream order. The basin area of each stream order is found with the GIS platform and try to find the relationship between mean basin area and stream order.
Table 4: order wise area characteristics

\begin{tabular}{|c|c|c|c|c|}
\hline Order & $\begin{array}{c}\text { No. of } \\
\text { Stream }\end{array}$ & $\begin{array}{c}\text { Area } \\
(\text { Sq Km })\end{array}$ & $\begin{array}{c}\text { Mean Area } \\
(\text { Sq Km })\end{array}$ & $\begin{array}{c}\text { Area } \\
\text { Ratio }\end{array}$ \\
\hline 1 & 693 & 862.26 & 1.24 & - \\
\hline 2 & 191 & 311.86 & 1.63 & 1.31 \\
\hline 3 & 47 & 279.86 & 5.95 & 3.65 \\
\hline 4 & 13 & 216.10 & 16.62 & 2.79 \\
\hline 5 & 3 & 76.76 & 25.58 & 1.54 \\
\hline 6 & 1 & 32.00 & 32.00 & 1.25 \\
\hline Total & 948 & 1779 & & \\
\hline
\end{tabular}

\subsubsection{Area Ratio $(A \mu)$}

Strahler [27] suggested finding area ratio with following formula:

$$
\mathrm{A} \mu=\frac{\overline{A_{\mu}}}{\overline{A_{\mu-1}}}
$$

Where, $\overline{A \mu}$ is a mean area of a given order and $\overline{A_{\mu-1}}$ is the mean area of preceding of the order.

Area ratio of Dibru river varies from 1.25 to 3.65 and shows that in $3^{\text {rd }}$ and $4^{\text {th }}$ order the area ratio is more as compare to other order stream.

\subsubsection{Law of basin area}

The cumulative mean basin area of successive higher order increased with geometrical series keeping in mind the mean basin area of first order and increasing with the constant area ratio. The relationship between cumulative mean area and stream order is highly positive and increase with increasing stream order. The correlation coefficient is 0.99

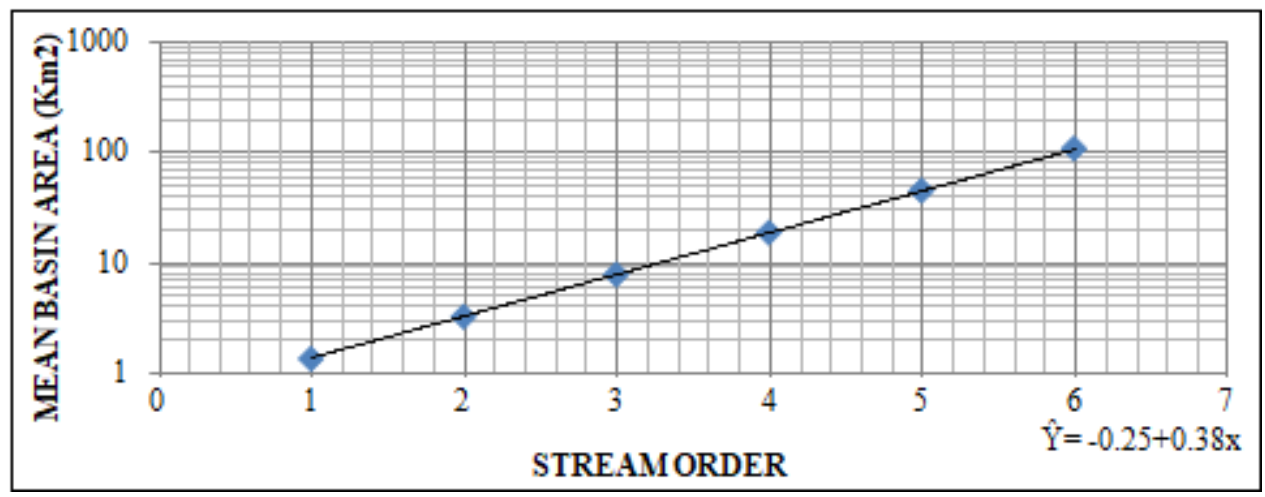

Figure 5: Relationship between stream order and mean basin area

\subsubsection{Drainage density $(D d)$}

Drainage Density refers to the total stream length per unit area of the basin. Drainage density is mainly control by the geological structure, slope, vegetation cover, climatic and sometimes human interference. According to Horton [9] Drainage density is the ratio of total length of all streams segment in a given drainage to the total area of that basin and usually it is derive as

$$
D=L / A
$$

Where, $\mathrm{L}$ is the total stream length and $\mathrm{A}$ is the total area of the basin.

The average drainage density of Dibru river basin is 1.04 $\mathrm{km} / \mathrm{sq} \mathrm{km}$. The drainage density is classified under four classes like very poor, poor, moderate and high drainage density categories. So $59.82 \%$ of the total area of the basin is cover by very poor categories, $35 \%$ of total area of the basin is occupied by poor categories, $4.53 \%$ of total area of the basin occupied by moderate categories and $0.19 \%$ of total basin area is occupied by high categories. Very poor categories of drainage density cover $1063.91 \mathrm{sq} \mathrm{km}$ of the basin and $3.35 \mathrm{sq} \mathrm{km}$ of the basin cover high drainage density. From the analysis the drainage density of Dibru river basin is $1.04 \mathrm{~km} / \mathrm{sq} \mathrm{km}$ which indicate that the basin is highly resistant permeable subsurface material and it range from base level slope to gently slope. 


\section{International Journal of Science and Research (IJSR) \\ ISSN: 2319-7064}

ResearchGate Impact Factor (2018): 0.28 | SJIF (2018): 7.426



Figure 6: Drainage Density map

Table 5: spatial distribution of drainage density

\begin{tabular}{|c|c|c|c|c|}
\hline Interval & Categories & Area & \% of Area & Cumulative Area \\
\hline $0-1.2$ & Very poor & 1063.91 & 59.82 & 1063.91 \\
\hline $1.2-2.3$ & Poor & 630.75 & 35.46 & 1694.66 \\
\hline $2.3-3.5$ & Moderate & 80.56 & 4.53 & 1775.22 \\
\hline $3.5-4.7$ & High & 3.35 & 0.19 & 1778.57 \\
\hline Total & & 1778.57 & & \\
\hline
\end{tabular}

\subsubsection{Stream frequency $(F)$}

Stream frequency refers to the total number of stream of the basin per unit area of the basin. Stream frequency is depends on geologic, topographic, vegetation cover and hydrological factors. According to Horton the stream frequency is define as the total number of stream segment of all orders per unit area.

\section{Stream frequency, $\mathrm{F}=\frac{N}{\mathrm{~A}}$}

Where, $\mathrm{N}$ is the total number of stream of the basin and $\mathrm{A}$ is the area of the basin.

The drainage frequency of the Dibru river basin is 0.53 segment / sq km. Due to low drainage frequency of Dibru river basin it shows that the region is highly permeable, vegetation covers, relief nature, rainfall and hydrological characteristics. It is categories under five classes viz. very poor, poor, moderate, high and very high stream frequency categories. The very poor categories cover a total of $81.82 \%$ of the basin area, poor categories cover a total of $16.46 \%$ of the basin area, moderate categories cover a total of $1.48 \%$ of basin area, high categories cover a total of $0.19 \%$ of the basin area and very high categories cover a total of $0.04 \%$ of the basin area. From the table 6 we came to conclusion that very poor categories of stream frequency cover an area of $1455.25 \mathrm{sq} \mathrm{km}$ of the basin and very high categories of stream frequency cover an area of $0.71 \mathrm{sq} \mathrm{km}$ of the basin area.

Table 6: Spatial distribution of stream frequency

\begin{tabular}{|c|c|c|c|c|}
\hline Interval & Categories & Area & \% of Area & Cumulative Area \\
\hline $0-3.1$ & Very poor & 1455.25 & 81.82 & 1455.25 \\
\hline $3.1-6.3$ & Poor & 292.83 & 16.46 & 1748.08 \\
\hline $6.3-9.4$ & Moderate & 26.36 & 1.48 & 1774.44 \\
\hline $9.4-12.5$ & High & 3.40 & 0.19 & 1777.84 \\
\hline $12.5-15.7$ & Very high & 0.71 & 0.04 & 1778.55 \\
\hline Total & & 1778.55 & & \\
\hline
\end{tabular}

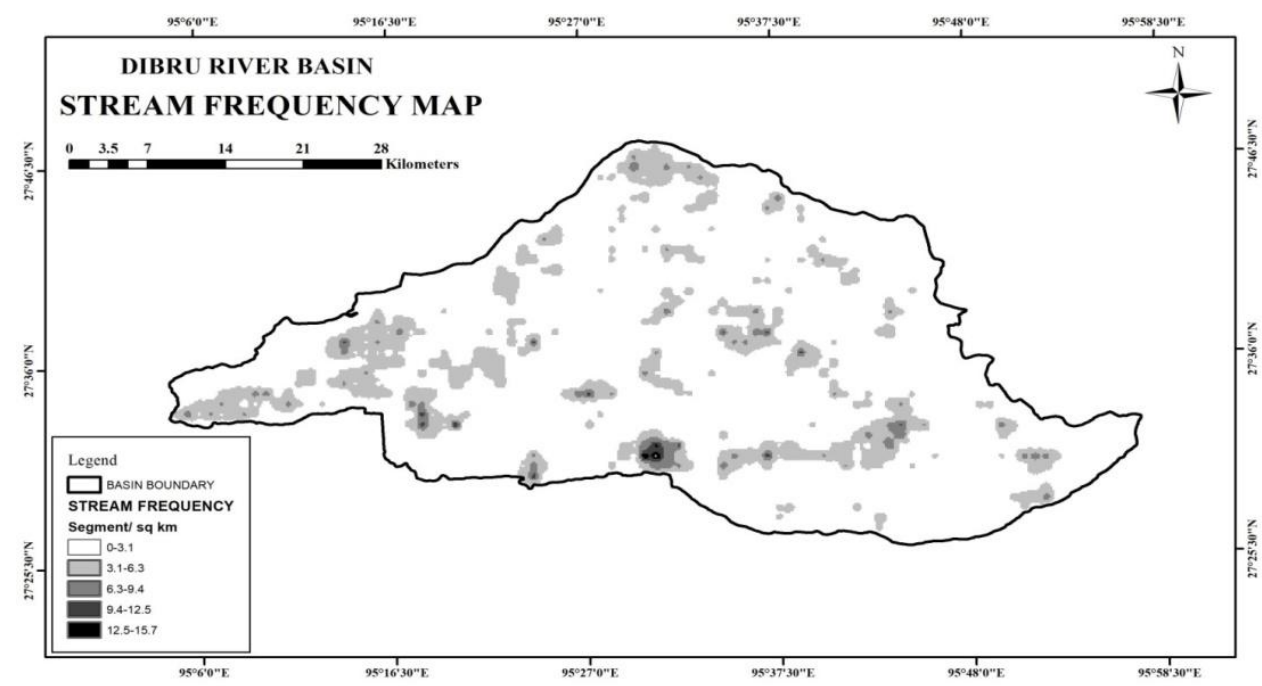

Figure 7: Stream Frequency map

Volume 8 Issue 8, August 2019 www.ijsr.net

Licensed Under Creative Commons Attribution CC BY 


\section{International Journal of Science and Research (IJSR) \\ ISSN: 2319-7064}

ResearchGate Impact Factor (2018): 0.28 | SJIF (2018): 7.426

\subsubsection{Drainage texture (Dt)}

Drainage texture is also important parameters of basin morphometric analysis as it helps in gaining the relative spacing between the stream lines. Drainage texture depends on several factors like climate, vegetation cover, soil type, infiltration capacity, relief aspects etc. The total numbers of stream segments of all the order per perimeter of that area [9].

$$
\mathrm{Dt}=\frac{N u}{P}
$$

Where $N u$ is the total numbers of all stream segment of all the order, $\mathrm{P}$ is perimeter of that area Horton [9] and the drainage texture value of Dibru river basin is 4.059. Smith classified drainage texture into five different textures categories i.e., very coarse $(<2)$, coarse $(2$ to 4$)$, moderate $(4$ to 6 ), fine (6 to 8 ), and very fine $(>8)$. Lower drainage density leads to coarse drainage texture and high drainage density leads to fine drainage texture. The average drainage density of Dibru basin is $1.04 \mathrm{~km} / \mathrm{sq} \mathrm{km}$ which can be said that the drainage texture of Dibru river basin falls in moderate categories of drainage texture, which indicate that the region geological structure is good in infiltration capacity, high permeable and lower run-off characteristics.

\subsubsection{Infiltration number (If)}

Faniran define infiltration number as the product of Stream frequency and Drainage density in order to analysis the infiltration characteristics of the watershed.

If $=F s \times D d[5]$

Where, Fs if Stream frequency and Dd is drainage density The Infiltration number of Dibru Basin is found 0.55. The lower the infiltration number, the higher the infiltration rate and low surface runoff due to gentle slope and vegetation cover.

\subsubsection{Texture ratio $(\mathrm{Rt})$}

Schumm (1965) define texture ratio is an important factor in the drainage morphometric analysis which is depending on the underlying lithology, infiltration capacity and relief aspects of the terrain. The texture ratio is expressed as the ratio between the first order streams and perimeter of the basin and it depends on the underlying lithology, infiltration capacity and relief aspects of the terrain. The texture ratio of Dibru river is 2.967 .

$$
R t=N\left(\frac{1}{p}\right)
$$

Where, $\mathrm{N}$ is first order streams and $\mathrm{P}$ is perimeter of the basin

\subsubsection{Constant of channel maintenance $(C)$}

Schumm [20] used the inverse of drainage density or the constant of channel maintenance as a property of landforms. The constant indicates the number of $\mathrm{Km}^{2}$ of basin surface required to develop and sustain a channel $1 \mathrm{~km}$ long. The constant of channel maintenance indicates the relative size of landform units in a drainage basin and has a specific genetic connotation [25]. The high value of $C$ has very less structural disturbances and less runoff conditions. The constant of channel maintenance of Dibru River is $0.961 \mathrm{~km}$.

\subsection{Relief Aspects}

\subsubsection{Basin relief $(H)$}

The Difference between the highest point of elevation from the source to the lowest point at the mouth of the river is defined as the total basin relief. The maximum elevation of the basin is $160 \mathrm{~m}$ and the minimum elevation of the basin is $108 \mathrm{~m}$. The total Basin relief of Dibru river basin is $52 \mathrm{~m}$. Basin relief is correlate with the channel slope and stream frequency.

$\mathrm{H}=$ maximum height $\sim$ minimum height

\subsubsection{Relief ratio $(\mathrm{Rr})$}

Schumm [20] define relief ratio as the ratio between total relief and the longest dimensions of the basin parallel to the main drainage line. Relief ratio has a close relation with the hydrologic characteristics and sediments loose particles thus depend on the relief of the basin.

$$
\mathrm{Rr}=\frac{H}{L b}
$$

Where $\mathrm{H}$ is basin relief and $\mathrm{Lb}$ is basin length

The relief ratio of Dibru river basin is 0.596 . Low relief ratio indicates that about the resistance of the basement rock and low slope degree.

\subsubsection{Longitudinal profile}

Long profile is defines as the length of the channel from source to mouth. It depends on the grade of the slope. Slope decline downwards due to discharge, tectonic activity, geologic structure, sediment transport, flow resistance, width and depth. The river from the source to mouth it carried its materials and deposited its sediment where it finds the equilibrium point or base level. The Dibru river origin at an altitude of about $155 \mathrm{~m}$ above mean sea level and runs up to $132.95 \mathrm{~km}$ and the river is at the mature stage which forms concave in the valley.

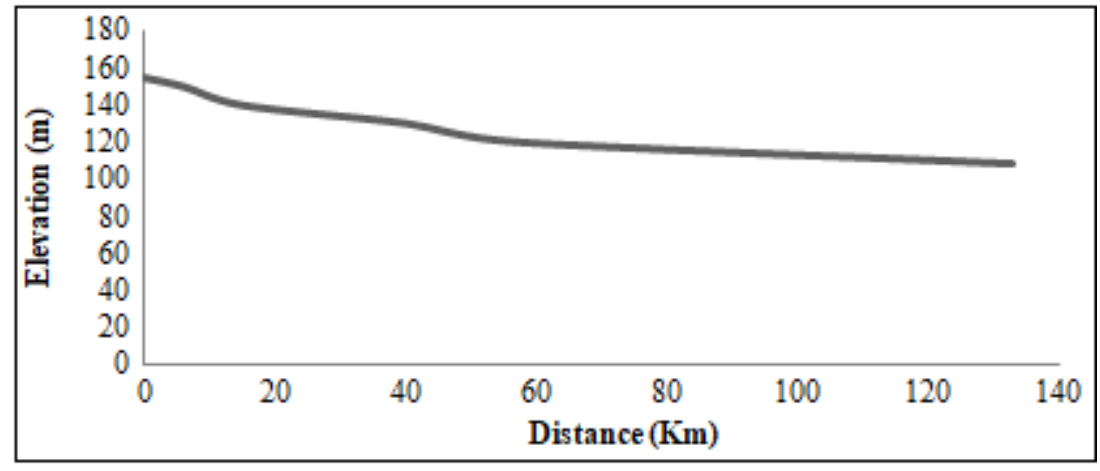

Figure 8: Long profile of Dibru river 


\section{International Journal of Science and Research (IJSR) \\ ISSN: 2319-7064}

ResearchGate Impact Factor (2018): 0.28 | SJIF (2018): 7.426

\subsubsection{Slope}

Slope is another important parameter of areal aspects of morphometric analysis. Slope is a ratio of vertical drop to horizontal distant and form by the earth tectonic or any denudation forces. There are many method to calculate slope analysis and contribution made by Rich (1916), [29], Raisz and Henry (1937), [23], Robinson (1948), [3] etc. Slope analysis is done with the help of contour extraction from the Toposheet (SOI), at $10 \mathrm{~m}$ interval using spatial analysis tools in GIS platform. The slope of the Dibru basin ranges between $0^{\circ}$ to $2.68^{\circ}$. This range of slope is categories into three classes as base level slope, nearly level slope and gently slope. The maximum area of basin about $65.40 \%$ of the total basin is cover by the Base level slope, nearly level slope cover an area of $29.77 \%$ and only $4.81 \%$ of the total area of the basin cover gently slope.

Table 7: Spatial distribution of slope

\begin{tabular}{|c|c|c|c|c|c|}
\hline Type of Slope & Class & $\begin{array}{c}\text { Area } \\
\text { (sq km) }\end{array}$ & $\begin{array}{c}\% \text { of } \\
\text { Area }\end{array}$ & $\begin{array}{c}\text { CF of } \\
\text { Area }\end{array}$ & $\begin{array}{c}\text { CF of } \\
\% \text { Area }\end{array}$ \\
\hline Base level slope & $0-0.5$ & 1162.568 & 65.40 & 1162.568 & 65.40 \\
\hline Nearly level slope & $0.5-1.0$ & 529.254 & 29.77 & 1691.822 & 95.17 \\
\hline Gently slope & $>1.0$ & 85.668 & 4.81 & 1777.49 & 99.98 \\
\hline Total & & 1777.49 & & & 100 \\
\hline
\end{tabular}

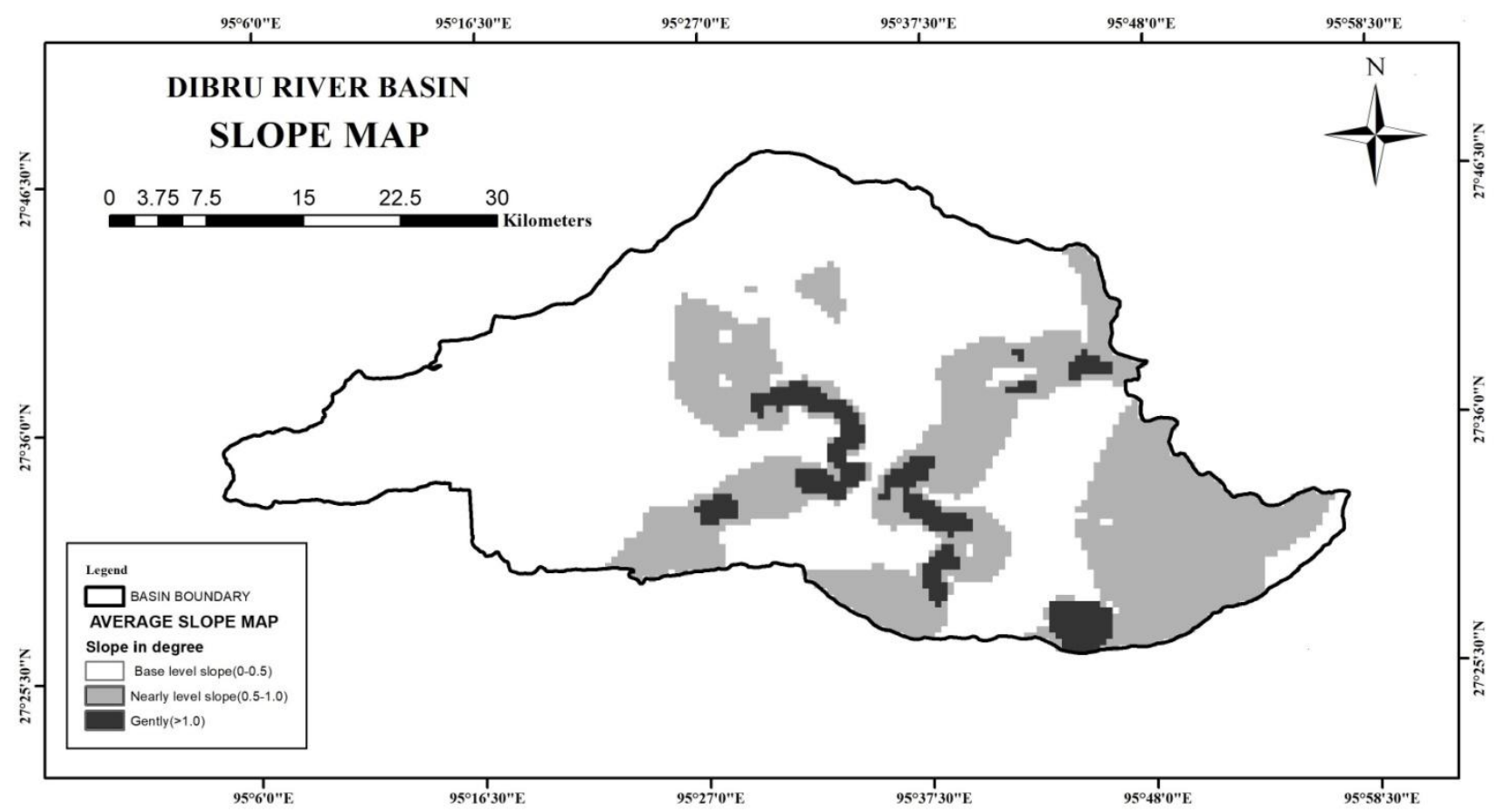

Figure 8: Slope map

\subsubsection{Law of Channel Slope}

Slope ratio is express as the ratio between the degree slopes of any given order to the next successive higher order of the basin. It is mathematically express as

$\mathrm{Rs}=\frac{S u}{S_{u+1}}$

Where, $S u$ is slope of a given order, $S_{u+1}$ is slope of next higher order

Table 8: Order wise slope ratio

\begin{tabular}{|c|c|c|}
\hline Order & Slope in degree & Slope ratio \\
\hline 1 & $0^{\circ} 4^{\prime} 26.63^{\prime \prime}$ & 1.279 \\
\hline 2 & $0^{\circ} 3^{\prime} 28.33^{\prime \prime}$ & 1.052 \\
\hline 3 & $0^{\circ} 3^{\prime} 18.01^{\prime \prime}$ & 1.066 \\
\hline 4 & $0^{\circ} 3^{\prime} 5.64^{\prime \prime}$ & 3.750 \\
\hline 5 & $0^{\circ} 0^{\prime} 49.5^{\prime \prime}$ & 1.302 \\
\hline 6 & $0^{\circ} 0^{\prime} 38^{\prime \prime}$ & - \\
\hline
\end{tabular}

Law of Channel slope is usually measure from the upper stage of the first order stream to the lower stage of the last order stream of the single master stream of the river. Usually the Law of channel slope is finding out with the ratio of vertical drop as to increase in horizontal distance of each order. Mean channel slope of each order is then derived and tabulated.

'The Law of channel slope' as propounded by R.E Horton [9] and applied by M. Morisawa [13] and Leopold and Miller (1956) states that mean channel slope decrease with increasing successive order in geometric series with constant slope ratio. The exponential function fitted to mean channel slope and stream order. 


\section{International Journal of Science and Research (IJSR) \\ ISSN: 2319-7064}

ResearchGate Impact Factor (2018): 0.28 | SJIF (2018): 7.426



Figure 10: Channel slope of Dibru river

4.3.6 Ruggedness number $(\mathrm{Rn})$

Strahler's (1968) ruggedness number is the product of basin relief and drainage density and usefully combines slope steepness with its length. The Ruggedness number of Dibru river basin is 0.054 . The low value of Ruggedness number indicates that there is low probability of soil erosion.

$$
R n=D d \times \frac{H}{1000}
$$

\subsection{Sub-Basin Morphometry of Dibru River Basin}

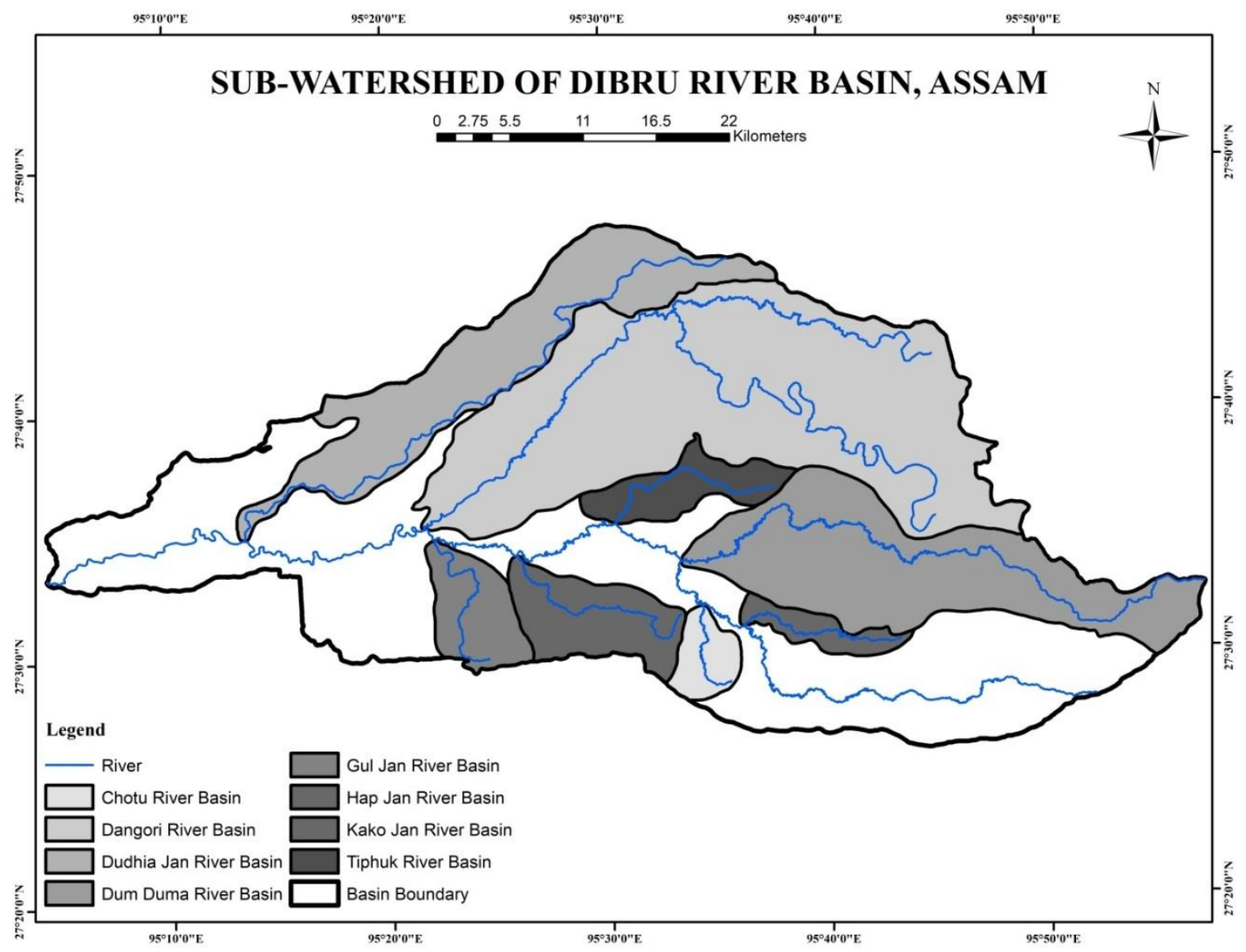

Figure 11: Sub-watershed of Dibru river basin

\section{Linear Aspects}

The morphometric analysis of Dibru river basin is carried out by the method of A.N Strahler [26], Horton's [8,9]. So, according to Strahler two first order stream segment give birth to second order stream, and if any lower order stream join the higher order it doesn't change it order and it carry so on. It is observed that Dibru river basin has the sixth order stream and its sub-watershed like, Dangori and Dum Duma has fifth order, Chotu, Gul Jan, Hap Jan, Tiphuk Jan and Dudhia Jan has fourth order and Kako Jan has third order stream. The maximum stream frequency is observed at first, second and third order stream. Hence it proved that stream frequency decrease with increasing order and vice versa and stream numbers also dependent on the type of lithology also.
The number of stream segment and stream order are calculated with the used of Arc GIS platform and the subwatershed basin are found with the Selection tool through which $\mathrm{i}$ extract the sub boundary and the stream. It is observed that stream segment decrease with increasing order and this may largely depend on physiographic, geomorphologic and geological condition of the basin. Horton [9] states that the numbers of streams of different orders in a given drainage tend closely to approximate an inverse geometric series in which the first term is unity and the ratio is the bifurcation ratio. According to this law the stream number is plotted against logarithmic scale on the $y$ axis and stream order on arithmetic scale on the $\mathrm{x}$ axis. The number of stream from lower order to higher order gradually

Volume 8 Issue 8, August 2019 www.ijsr.net 


\section{International Journal of Science and Research (IJSR) \\ ISSN: 2319-7064}

ResearchGate Impact Factor (2018): 0.28 | SJIF (2018): 7.426

decrease with increasing order and there's relationship is negative correlation between them.

Bifurcation ratio is the ratio of the number of stream segment in a given order $\left(\mathrm{N}_{\mathrm{u}}\right)$ to the number of stream of next higher order $\left(\mathrm{N}_{\mathrm{u}+1}\right)$. Bifurcation ratio is dimensionless property of drainage basin which is controlled by drainage density, lithological characteristics, basin shapes, basin area etc. According to R.E Horton, Bifurcation ratio between about 2.00 represent flat or rolling basin, 3.0-4.0 represents mountainous or hilly dissected basin. The bifurcation ratio of Dibru river basin vary from 3.00-4.33 and the mean bifurcation ratio is 3.72 , although the basin fall in plain region instead it shows that basin drainage is network from hilly region. There is variation in bifurcation ratio from lower order to higher order due to possibility in physiographic and lithology structure. The sub-watershed bifurcation ratio range from 2.5-5.58 and the lower values of $\mathrm{Rb}$ are characteristics of the watersheds, which have suffered less structural disturbances [26] and the drainage pattern has not been distorted because of the structural disturbances [14] and high values of $\mathrm{Rb}$ indicates strong structural control on the drainage pattern.

According to Horton [9], the cumulative stream length of successive higher order increase in geometrical progression starting with the mean length of the first order segments with constant length ratio. The study of length of streams, with its mean values in relation to order number, is of great importance in the study of the drainage characteristic of a basin. The Higher number of stream with shorter length are observed where the lithological and bedrock are less permeable and lesser number of stream with longer stream length are observed where the landscape characteristics is permeable and well drained watershed. The cumulative stream length of Dibru and sub-watershed is positively correlated with the stream order from lower order to higher order (i.e. 1.31, 1.81, 5.90, 15.17, 17.76, and 75.18 from lower order to higher order 1, 2, 3, 4, 5 and 6).

Horton law [9] of stream length ratio point out that mean stream length segment of each successive orders of a basin tends to approximate a direct geometric series with mean stream length increasing towards higher order of stream. The change in stream length ratio is shown in table 9 and these variations of stream length ratio is depends on slope and topography and it indicates the stage of the river.

The Length of Overland flow of Dibru river and its subwatershed basin are comparatively similar and fall in same stage of landform development and the Lemniscate's value shows that maximum area in the region inceptions with large numbers of streams of higher order and the Channel pattern of the main river and its sub-watershed fall in the sinuous courses.

\section{Relief Aspects}

Under Relief aspects the parameters are like Basin relief, Relief ratio and Ruggedness numbers and long profile help in analysing about the Channel slope, stream frequency, runoff condition, infiltration, permeability and erosion characteristics of the basin. The Basin relief of the Dibru river basin is $52 \mathrm{~m}$ and its sub-watershed range from $12 \mathrm{~m}$ to $52 \mathrm{~m}$ and hence proved that the basin is in base level slope to gently slope where the runoff condition is low and high permeability and infiltration. The Ruggedness number analysis about the structural complexity of the terrain and the low value of ruggedness number indicate low probability of erosion power of the river. Long profile of Dibru sub basins are shown in figure 12. It is observed from the figure that the sub tributaries of Dibru river is in mature stage.

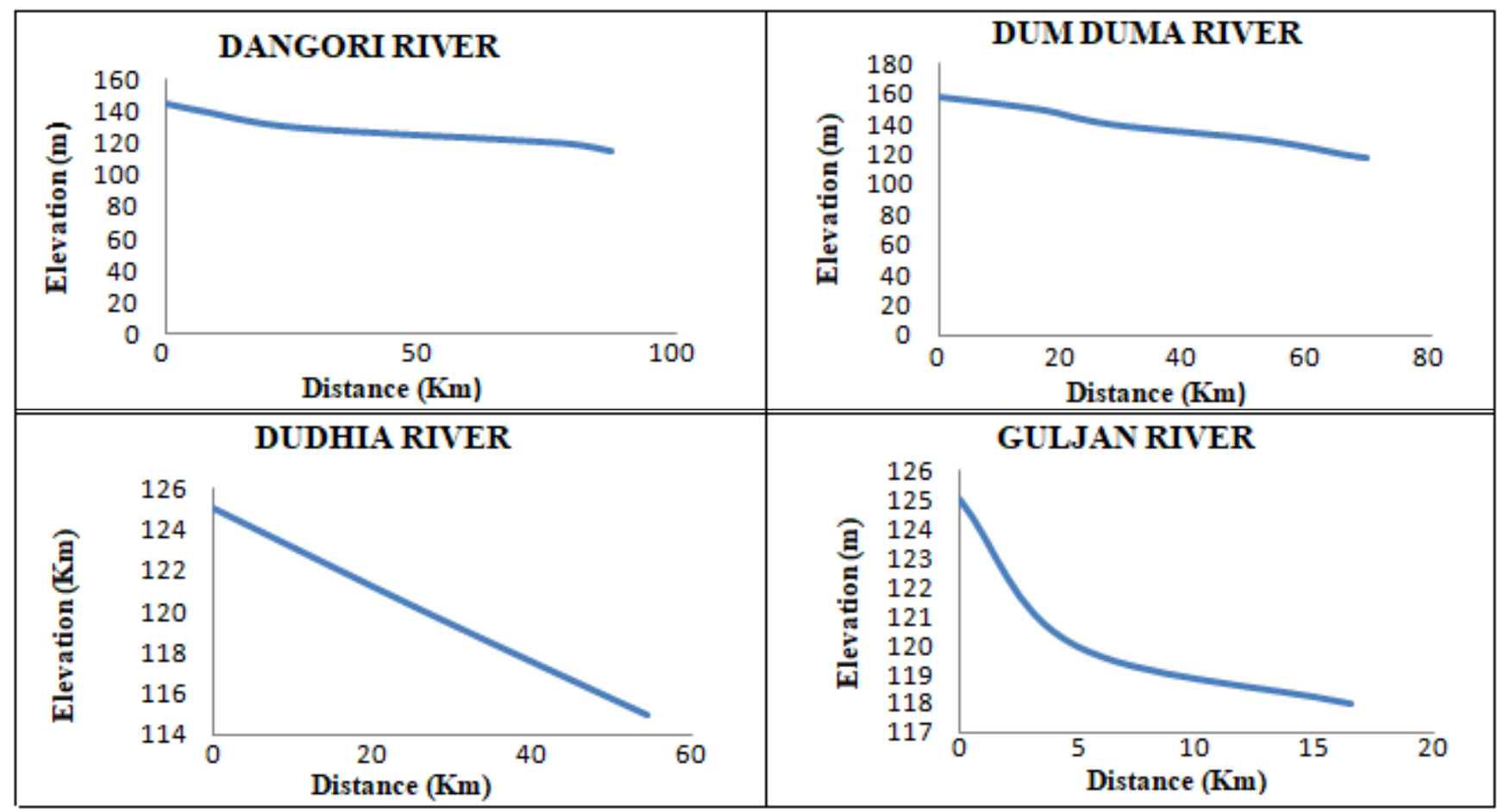

Volume 8 Issue 8, August 2019 www.ijsr.net 
International Journal of Science and Research (IJSR)

ISSN: 2319-7064

ResearchGate Impact Factor (2018): 0.28 | SJIF (2018): 7.426



Figure 12: Long profile of different sub basin of Dibru basin

Table 9: Linear aspects at different Sub basin

\begin{tabular}{|c|c|c|c|c|c|c|c|c|c|c|c|c|c|c|c|}
\hline \multirow{2}{*}{ Name } & \multirow{2}{*}{$\begin{array}{c}\text { Basin } \\
\text { length } \\
(\mathrm{km})\end{array}$} & \multirow{2}{*}{\begin{tabular}{|c|} 
Basin \\
perimeter \\
$(\mathrm{km})$
\end{tabular}} & \multirow{2}{*}{\begin{tabular}{|c|} 
Number \\
of \\
stream
\end{tabular}} & \multicolumn{6}{|c|}{ Drainage order } & \multirow{2}{*}{$\begin{array}{c}\text { Stream } \\
\text { length } \\
(\mathrm{km})\end{array}$} & \multirow{2}{*}{$\begin{array}{c}\text { Bifurcation } \\
\text { ratio }\end{array}$} & \multirow{2}{*}{$\begin{array}{l}\text { Length } \\
\text { ratio }\end{array}$} & \multirow{2}{*}{$\mid \begin{array}{c}\text { Sinuosity } \\
\text { index }\end{array}$} & \multirow{2}{*}{ Lemniscate's } & \multirow{2}{*}{$\begin{array}{l}\text { Length of } \\
\text { overland } \\
\text { flow }\end{array}$} \\
\hline & & & & 1 & 2 & 3 & 4 & 5 & 6 & & & & & & \\
\hline Dibru Main stream & 87.13 & 233.54 & 948 & 693 & 191 & 47 & 13 & 3 & 1 & 1863 & 3.72 & $1.17-4.23$ & 1.36 & 4.26 & 0.48 \\
\hline Dum duma & 39.45 & 94.55 & 140 & 101 & 30 & 6 & 2 & 1 & & 233.85 & 3.34 & 0.30 & 1.34 & 6.28 & 0.53 \\
\hline Chotu & 7.26 & 20.53 & 23 & 15 & 5 & 2 & 1 & - & & 21.70 & 2. & 0.58 & .20 & 1.97 & 1 \\
\hline Kako j & 12.87 & 31.79 & 38 & 31 & 6 & \begin{tabular}{|l|l|}
1 & \\
\end{tabular} & - & - & & 39.70 & 5.58 & $0.93-28.33$ & 1.24 & 6.54 & 0.32 \\
\hline Gul jan & 10.53 & 30.72 & 29 & 18 & 7 & 3 & 1 & - & & 34.52 & 2.63 & $0.90-11.70$ & 1.22 & 2.16 & 0.74 \\
\hline Hap jan & 14.81 & 39.69 & 75 & 52 & 17 & 5 & 1 & - & & 77.02 & 3.81 & 1.01-6.39 & 1.16 & 3.06 & 0.46 \\
\hline Dudhi ja & 44.7 & 112 & 95 & 71 & 20 & 30 & 1 & - & & 256.2 & 4.40 & $1.70-3.91$ & 1.12 & 10.29 & 0.38 \\
\hline Dangor1 & 45.46 & 130.4 & 220 & 159 & \begin{tabular}{|l|}
44 \\
\end{tabular} & 12 & 4 & 1 & & 483.87 & 3.56 & $1.72-3.26$ & 1.46 & 4.02 & 0.53 \\
\hline Tiphuk jan & 14.33 & 40.04 & 53 & 40 & \begin{tabular}{|l|}
10 \\
\end{tabular} & 2 & 1 & - & - & \begin{tabular}{|l|}
62.79 \\
\end{tabular} & 3.66 & $1.91-3.15$ & 1.16 & 4.23 & 0.38 \\
\hline
\end{tabular}

Table 10: Area and relief characteristics at different sub basin

\begin{tabular}{|c|c|c|c|c|c|c|c|c|c|c|c|c|}
\hline Name & $\begin{array}{l}\text { Area } \\
\left(\mathrm{km}^{2}\right)\end{array}$ & \begin{tabular}{|c|} 
Drainage \\
density \\
$\left(\mathrm{km} / \mathrm{km}^{2}\right)$ \\
\end{tabular} & $\begin{array}{c}\text { Stream } \\
\text { frequency } \\
\left(\mathrm{seg} / \mathrm{km}^{2}\right) \\
\end{array}$ & $\begin{array}{c}\text { Infiltration } \\
\text { number }\end{array}$ & $\begin{array}{l}\text { Form } \\
\text { factor }\end{array}$ & $\begin{array}{l}\text { Elongation } \\
\text { ratio }\end{array}$ & $\begin{array}{l}\text { Circulatory } \\
\text { ratio }\end{array}$ & $\begin{array}{c}\text { Relief } \\
\text { ratio }\end{array}$ & \begin{tabular}{|c|} 
Constant of \\
channel \\
maintenance \\
\end{tabular} & $\begin{array}{c}\text { Texture } \\
\text { ratio }\end{array}$ & \begin{tabular}{|c|}
$\begin{array}{c}\text { Basin } \\
\text { relief } \\
(\mathrm{m})\end{array}$ \\
\end{tabular} & $\begin{array}{c}\text { Ruggedness } \\
\text { number }\end{array}$ \\
\hline Dibru main stream & 1779 & 1.04 & 0.53 & 0.55 & 0.23 & 0.52 & 0.40 & 0.59 & 0.96 & 2.96 & 52 & 554 \\
\hline Dum duma & 247.7 & 0.94 & 0.56 & 0.52 & 0.15 & 0.44 & 0.34 & 1.01 & 1.06 & 1.06 & 40 & 0.037 \\
\hline Chotu & 26.72 & 0.81 & 0.86 & 0.69 & 0.50 & 0.78 & 0.79 & 1.65 & 1.23 & 0.73 & 12 & 0.009 \\
\hline Kako jan & 25.31 & 1.56 & 1.50 & 2.34 & \begin{tabular}{|l|}
0.15 \\
\end{tabular} & 0.42 & 0.31 & 1.39 & 0.64 & 0.97 & 18 & 0.028 \\
\hline Guljan & 51.22 & 0.67 & 0.56 & 0.37 & 0.46 & 0.72 & 0.68 & 1.13 & 1.49 & 0.58 & 12 & 0.008 \\
\hline Hap jan & 71.65 & 1.07 & 1.04 & 1.11 & 0.32 & 0.62 & 0.57 & 1.08 & 0.93 & 1.31 & 16 & 0.017 \\
\hline Dudhia jan & 194.1 & 1.31 & 0.48 & 0.62 & \begin{tabular}{|l|}
0.09 \\
\end{tabular} & 0.31 & 0.19 & 0.31 & 0.76 & 0.63 & 14 & 0.018 \\
\hline Dangori & 513.6 & 0.94 & 0.42 & 0.39 & 0.24 & 0.51 & 0.37 & 0.65 & 1.06 & 1.21 & 30 & 0.028 \\
\hline Tiphuk jan & 48.43 & 1.29 & 1.09 & 1.40 & 0.23 & 0.50 & 0.37 & 0.76 & 0.77 & 0.99 & 11 & 0.01 \\
\hline
\end{tabular}

\section{Areal Aspects}

The morphometric parameters of areal aspects are like basin shape, drainage density, stream frequency, infiltration number, drainage texture, texture ratio, Constant of Channel maintenance etc. All this parameters help in analysing about the shape of the basin whether it is elongation or Circulatory. Drainage density, Stream frequency and Infiltration number thus depend on the topography, geologic condition, soil properties, vegetation cover, climate, hydrologic characteristics and also on the interference of human behaviour. Drainage texture, Texture ratio and Constant of Channel maintenance they analysis on the infiltration, permeability and thus it depend upon the lithological structure, texture of the sediment and runoff condition.

\section{Volume 8 Issue 8, August 2019} www.ijsr.net

Licensed Under Creative Commons Attribution CC BY 


\section{International Journal of Science and Research (IJSR) \\ ISSN: 2319-7064}

ResearchGate Impact Factor (2018): 0.28 | SJIF (2018): 7.426

There are various ways to find the shape of the basin which are formulated by some illustrious persons like Horton's, V.C Miller and Schumm in bringing out the concept. The method like Form factor, Circulatory ratio and Elongation ratio method are used to find the basin shape. This method helps in about the outflow of the river and runoff condition. If the value is near to 0 then it is term as Elongation basin and the value near to 1 is terms as Circular basin. The characteristics of Elongation basin is that the outflow is longer in duration as compare to circular basin. Using all the method the Dibru river basin fall in Elongation shape basin and the water stay for longer duration and its sub-watershed all fall in category of Elongation shape except Chotu River which fall in Circular shape basin.

Stream frequency is defined as the total number of stream segment per unit area. Drainage density is define as the total stream segment per unit area and. The drainage frequency of the Dibru river basin is 0.53 segment / sq $\mathrm{km}$ and the subwatershed of the Dibru river like Dum Duma $(0.56 \mathrm{seg} / \mathrm{sq}$ $\mathrm{km})$, Chotu (0.86seg /sq km), Kako Jan (1.50 seg/ sq km), Gul Jan (0.56 seg /sq km), Hap Jan (1.04 seg/ sq km), Dudhia Jan (0.48 seg /sq km) and Dangori(0.42 seg/ sq km) sub-watershed they all have low stream frequency. Due to low drainage frequency of Dibru river basin and its subwatershed it shows that the region is highly permeable, vegetation cover, relief nature, rainfall and hydrological characteristics. Dibru River Basin is categories under fiver class interval viz. very poor, poor, moderate, high and very high stream frequency categories. The very poor categories cover a total of $81.82 \%$ of the basin area, poor categories cover a total of $16.46 \%$ of the basin area, moderate categories cover a total of $1.48 \%$ of basin area, high categories cover a total of $0.19 \%$ of the basin area and very high categories cover a total of $0.04 \%$ of the basin area. From the table we came to conclusion that very poor categories of stream frequency cover an area of $1455.25 \mathrm{sq}$ $\mathrm{km}$ of the basin and very high categories of stream frequency cover an area of $0.71 \mathrm{sq} \mathrm{km}$ of the basin area.

The drainage density of Dibru river basin is $1.04 \mathrm{~km} / \mathrm{sq} \mathrm{km}$ and its sub-watershed is also computed in the GIS platform. The drainage density of Dibru River Basin is classified under four class interval like very poor, poor, moderate and high drainage density categories. So $59.82 \%$ of total area of the basin is cover by very poor categories, $35 \%$ of total area of the basin is occupied by poor categories, $4.53 \%$ of total area of the basin occupied by moderate categories and $0.19 \%$ of total basin area is occupied by high categories. Very poor categories of drainage density cover $1063.91 \mathrm{sq}$ $\mathrm{km}$ of the basin and $3.35 \mathrm{sq} \mathrm{km}$ of the basin cover high drainage density. From the analysis the drainage density of dibru river basin is $1.04 \mathrm{~km} / \mathrm{sq} \mathrm{km}$ and its sub-watershed like Dum Duma (0.94 km/ sq km), Chotu $(0.81 \mathrm{~km} / \mathrm{sq} \mathrm{km})$, Kako Jan $(1.56$ km/ sq km), Gul Jan (0.67 km /sq km), Hap $\operatorname{Jan}(1.07 \mathrm{~km} / \mathrm{sq} \mathrm{km})$, Dudhia $\operatorname{Jan}(1.31 \mathrm{~km} / \mathrm{sq} \mathrm{km})$ and Dangori $(0.94 \mathrm{~km} / \mathrm{sq} \mathrm{km})$ which indicate that the basin is highly resistant permeable subsurface material, vegetation cover and it range from base level slope to gently slope. Infiltration number of Dibru River and its sub-watershed shows that lower infiltration number represent higher level of infiltration rate due to low surface runoff, vegetation cover and gentle slope.
Drainage texture helps in gaining the relative spacing between of the stream and thus depends on several factors like climate, vegetation cover, soil type, infiltration capacity, relief aspects etc. The total numbers of all stream segment of all the order per perimeter of that area [9]. Smith [24] classified drainage texture into five different textures i.e., very coarse $(<2)$, coarse ( 2 to 4$)$, moderate (4 to 6 ), fine (6 to $8)$, and very fine $(>8)$. Lower drainage density leads to coarse drainage texture and high drainage density leads to fine drainage texture. So the drainage density of the study area is $1.04 \mathrm{~km} / \mathrm{sq} \mathrm{km}$ which can be said that the drainage texture of the Dibru River basin and its sub-watershed falls in very coarse to moderate categories (4.059) as classified by Smith in 1950, which indicate that the region geological structure is good in infiltration capacity, high permeable and lower run-off characteristics. Texture ratio is an important factor in the drainage morphometric analysis which is depending on the underlying lithology, infiltration capacity and relief aspects of the terrain.

As a property of landforms the constant of channel maintenance $(\boldsymbol{C})$ required to develop and sustain a channel of $1 \mathrm{~km}$ long. The constant of channel maintenance indicates the relative size of landform units in a drainage basin and has a specific genetic connotation [25]. The constant of channel maintenance of Dibru River basin is $0.961 \mathrm{~km}^{2} \mathrm{~km}^{-1}$ and the sub-watershed of Dibru river basin range from 0.64 $1.49 \mathrm{~km}^{2} \mathrm{~km}^{-1}$, and indicate that high value of $\boldsymbol{C}$ has very less structural disturbances and less runoff conditions and thus depends on the rock type, permeability, climatic regime, vegetation cover and relief as well as duration of erosion (Schumm, 1956).

\section{Conclusion}

After formulation of various morphometric analyses with the help of Survey of India toposheet using GIS tools which give more appropriate sense data than conventional methods. Various parameters are correlates with one another in bringing the various significance changes in the basin. The basin show a positive relationship between stream order and mean stream length and mean basin area and hence prove that with increase of stream order there is increase in mean stream length and mean basin area The bifurcation ratio of Dibru river is 3.72 which indicate that the water flow is regular and variation in stream length ratio is identified due to variation of slope and topography and it indicate the stage of the river. The basin is in elongation in shape and hence it said that when the basin is in elongation, the outflow of water is slow and stay for longer duration and maintence a constant channel of $0.961 \mathrm{~km}$. The Drainage density and drainage frequency of Dibru River is $1.04 \mathrm{~km} / \mathrm{sq} \mathrm{km}$ and $0.53 \mathrm{segment} / \mathrm{sq} \mathrm{km}$ which shows that the basin lithology structure is highly resistance and permeable due to slope of the basin, vegetation cover and hydrologic characteristics and the texture of the basin is in moderate in coarse. The Relief aspects of the basin are very important as the runoff, outflow and transportation of sediment depend on the slope and nick point is observed in the long profile of the main stream that is Dibru River. As a result the geologic structure, slope and hydrologic factors have a great implication on the processes of landforms development. Geospatial tools are the most reliable in better understanding about the nature of 


\section{International Journal of Science and Research (IJSR) \\ ISSN: 2319-7064}

ResearchGate Impact Factor (2018): 0.28 | SJIF (2018): 7.426

landforms, drainage patterns characteristics and also for basin area planning and management.

\section{References}

[1] Agarwal, C.S (1998), "Study of Drainage pattern through aerial data in Naugarh area of Varanasi district U.P. Journal of the Indian Society of Remote Sensing 26: 169-175.

[2] Brice, J.C (1964), "Channel patterns and terraces of the Loup Rivers in Nebraska. Geological Survey Professional Paper 422-D.

[3] Calef, W.C (1950), "Form and Process, Cambridge University Press", London, pp 473.

[4] Chorley, R.J.( 1977), "The Drainage Basin as the Fundamental Geomorphic Unit in Chorley, R.J.(ed), Introduction to Fluvial Processses, Methuen, London, pp.30-52.

[5] Faniran, A (1968), "The Index of Drainage Intensity- A Provisional New Drainage Factor" , Australian Journal of Science, 31, pp 328-330.

[6] Gabale, S.M. and Pawar, N.R., (2015), "Quantitative Morphometric Analysis of Ambilodha (Rivulet) in Pune, Maharashtra, India", IOSR Journal of Environmental Science, Toxicology and Food Technology, v 9, pp 41-45.

[7] Hajam, R. A., Hamid A. and Bhat S., (2013), "Application of Morphometric Analysis for Geohydrological studies using Geo-spatial Technology- A Case study of Vishav Drainage Basin", Hrdrology Current Research, vol 4, pp 2-8.

[8] Horton's, R.E (1932), "Drainage Basin Characteristics", Transactions, American Geophysical Union, 13, pp 35061.

[9] Horton, R.E. (1945) "Erosional development of streams and their drainage basins: Hydrophysical approach to quantitative morphology", Geol. Soc.Am. Bull. 56, pp. 275-370.

[10] Kulkarni, M.D., (2015), "The Basic Concept to Study Morphometric Analysis of River Drainage Basin: A Review", International Journal of science and Research, vol 4, pp 2277-2278.

[11]Meitei, T. M., (2010), "Lake Catchment Geomorphology", Kamakhya Book Agency (India), Guwahati, pp 168-169.

[12] Miller's, V.C (1953), “A Quantitative Geomorphic Study of Drainage Basin Characteristics in the Clinch Mountain Area.Virginia and Tennessee. Department Of Geology, Columbia University.

[13] Morisawa, M.E., (1959), "Relation of quantitative geomorphology to stream flow in representative watersheds of the Applachian Plateau Province, Columbia University, Office of Naval Research, Project NR 389-042, Technical Report 20.

[14] Nag, S.K (1998), "Morphometric analysis using remote sensing technique in the Chaka Sub-basin, Purulia District, West Bengal: Journal of Indian Society of Remote Sensing 26: 69-76.

[15] Obi Reddy et al., (2002), "GIS for morphometric analysis of drainage basins. Geological Survey of India 11: 9-14.

[16]Pareta, K., and Pareta, U, (2011), "Quantitative Morphometric Analysis of a Watershed of Yamuna
Basin, India using ASTER (DEM) and GIS", International Journal of Geomatics and Geosciences, vol 2 (1), pp 249-266.

[17] Patton, P. \& Baker, V (1976), "Morphometry and floods in Small Drainage Basin Subject of Diverse Hydrogeomorphic Controls. Water Resources Research, 12, 441-952.

[18] Saikia, R. and Thakuriah, G., (2015), "Practical Geography", EHB Publishers (India), Guwahati, pp 2641.

[19] Sarma, J. N., Acharjee S. and Gogoi, C., (2011), "Application of DEM, Remote Sensing and Geomorphic Studies in Identifying a Recent or perhaps Neogene Upwarp in the Dibru River Basin, Assam, India", J. Indian Soc. Remote Sens., DOI 10.1007/S12524-011-0115-1.

[20] Schumm's, S.A (1956), “Evolution of Drainage Systems \& Slopes in Badlands at Perth Anboy, New Jersey" , Bulletin of the Geological Society of America, 67, pp 597-646.

[21] Singh, S. (1998), “Geomorphology”, Prayag Pustak Bhawan Publishers (India), pp 382.

[22] Singh, Savindra, (2015), "Fundamentals of Hydrology", Pravalika Publication Allahabad (India), pp 317-318.

[23] Smith, G.H (1938-39), "The Morphometry of Ohio: The Average Slope of the Land (abstract)", Annals of the Association of American Geographers, 29, pp 94.

[24] Smith, K.G (1950), "Standards for grading textures of erosional topography", Am. Jour. Sci., 248: pp. 655688.

[25] Strahler, A.N (1957), "Quantitative analysis of watershed geomorphology. American Geophysical Union Transactions 38: 912-920.

[26] Strahler's, A.N. (1964) "Quantitative geomorphology of drainage basin and channel network" in Chow, V.T. (ed) Handbook of Applied Hydrology. McGraw Hill Company, New York, Section 4, part II.

[27] Strahler, A.N, (1969), "Physical Geography, $3^{\text {rd }}$ edition, John Wiley and Sons, Inc. New York.

[28] Thakuriah, G., Jaiswal M. and Saikia, R., (2012), "Watershed Based Drainage Morphometric Analysis of Diyung River, Assam (India) using Geospatial Tools", The Clarion: International Multidisciplinary Journal, vol 1 (2), pp 33-44.

[29] Wentworth, C.K (1930), "A Simplified Method of Determining the Average Slope of Land Surfaces", American Journal of Science, 21, pp 184-194. 